\title{
How to Improve the Contribution of Roads to the Economic Growth in Countries Whose Development Is Lagging Behind: The Case of Côte d'Ivoire
}

\author{
Fulgence Zran Goueu \\ Department of Economics, Peleforo Gon Coulibaly University, Korhogo, Ivory Coast, Cote d'Ivoire \\ Email address: \\ goueuzf@hotmail.com, goueuzf25@gmail.com

\section{To cite this article:} \\ Fulgence Zran Goueu. How to Improve the Contribution of Roads to the Economic Growth in Countries Whose Development Is Lagging \\ Behind: The Case of Côte D'Ivoire. American Journal of Traffic and Transportation Engineering. Vol. 5, No. 1, 2020, pp. 8-19. \\ doi: $10.11648 /$ j.ajtte.20200501.12
}

Received: December 11, 2019; Accepted: January 29, 2020; Published: April 13, 2020

\begin{abstract}
Côte d'Ivoire has based its economic development on export-oriented agriculture of primary products (coffee, cocoa). The strong economic growth, called The «Ivorian Economic Miracle» of the years 1970 was supported by transport infrastructures and roads in particular. The extensive degradation of national roads has impacted negatively on the country's economic growth. This present study analyzes the contribution of roads to Ivorian national growth, mostly that of the sub-component: roads maintenance. The econometric study on time series is conducted using Eviews, and takes the actual maintenance budgets actually executed per capita as proxy for road investments. The results of short and long-term estimates show Ivorian private and public investments, exports and the labor force highly contribute to national growth, thus they are important channels of Ivorian growth. The negative impact of the budget really realized per capita on GDPR $(-4.6 \%)$ thus demonstrates the effect of reducing roads to growth in Côte d'Ivoire. This confirms the hypothesis that the poor state of roads contributes to the country's declining growth. For Ivorian roads contribute positively to the national economy. We have determined thresholds for roads maintenance investments compared to national public and private investments, respectively $901.18 \%$ and $93.06 \%$. These thresholds improve the contribution of roads maintenance at $79.65 \%$ and $64.62 \%$ proportionally to public and private investments. In order to enable roads to contribute positively to Côte d'Ivoire's economic growth, the Ivorian state must index the executed budget to public or private investment in proportion to the thresholds set above.
\end{abstract}

Keywords: Roads Maintenance, Economic Growth, Roads Infrastructures, Public and Private Investments

\section{Introduction}

Infrastructures in general and transport infrastructures in particular are factors of social development and, regional and national economic growth. They provide direct support for productive activities and facilitate the movement of goods and people. They generate externalities. However, with external effects, the social optimum is no longer reached, so there is a need for the State intervention to reach an acceptable level of welfare of the community. Among the constituents of transport infrastructures, we are particularly interested in roads. Roads interconnect production and/or storage areas to the different distribution and marketing zones. They promote the creation and (re)localization of localities (villages and towns), units and/or production activities; but also the development of trade and leisure. Hence, the slow development of Africa results from the poor state of its infrastructures [1].

The excessive cost of investment in roads and their gestation periods oblige the public authorities to be generally the only investors, leaving the operation and management to private structures. The financial fragility of lagging States in development such as Côte d'Ivoire, understates the financing of road infrastructures. However, the productive effect of infrastructures depends on the magnitude and nature of the investment, while the design of the project, its rational management and its integration in the existing equipment often cause problems or various difficulties. 
Moreover, generally speaking, the conservation and sustainable management of infrastructures and roads in particular seem to be irrelevant in many studies. We are also interested in roads maintenance as a key factor in Côte d'Ivoire's economic growth. Indeed, roads maintenance takes into account the induced effects and therefore the direct and indirect effects of transport on growth. Thus, roads maintenance better reflects the roads supply in a delayed-growing country such as Côte d'Ivoire.

The economic and social development of Côte d'Ivoire in the $1970 \mathrm{~s}$ was supported and maintained by the implementation of significant road infrastructures. If the country has built a large high quality of roads with more than $82,000 \mathrm{~km}$, these roads have allowed Côte d'Ivoire to be the most endowed nation with road infrastructures in West Africa until the 1990s, according to the National Bureau of Technical Studies and Development (NBTSD). Also, the gloominess of their current state could make them one of the factors hindering the current economic growth. The major part of this network was built between the 1960s and 1970s, years of the country's strong economic growth called the economic boom years or "Ivorian miracle". The Ivorian medium growth rate was nearly $8 \%$ [2-4].

Therefore, we suppose that the poor state of Ivorian roads impacts negatively on the country's economic growth, and that there are levels of spending on roads that contribute positively to national growth.

This paper, while defining the nature of road infrastructures contribution to Ivorian economic growth, aims to determine how to improve roads contribution to national economic growth. The study assesses road profitability thresholds, by defining at which level of investment roads have a positive impact on the country's growth.

It is structured as follow: Firstly it is the analysis of the development and characteristics of Ivorian roads (section 1), secondly the methodological presentation (section 2), thirdly the discussion of the preliminary results obtained by the OLS is given (section 3); then the determination of profitability thresholds of road investments (section 4), and finally the conclusion (section 5).

\section{Developments and Characteristics of the Ivorian Road Network}

\subsection{Definition and Characteristics of the Ivorian Road Network}

The law of 1983 essentially sets out roads as means of communication such as large-scale highways or primary roads, secondary and tertiary roads, bypasses and radials roads, triumphal lanes and expressways, work of operation and disenclavement work.

Ivorian modern roads are classified and registered in categories A, B, C and D according to the vocation of the road and on the basis of the definition of thresholds or levels of traffic. The Ivorian road network (covered and unpaved) contains a motorway of $231 \mathrm{~km}$ (north motorway) $+18 \mathrm{~km}$ of expressway of Grand-Bassam according to AGEROUTE in 2016; national roads or Class A roads (7006 km length of which $64.42 \%$ and paved $35.58 \%$ on land) connect the Prefecture capitals with each other and ensure the main links with neighbouring countries. It also contains regional roads of class B of total linearity of $8271 \mathrm{~km}$ with $21.10 \%$ of paved roads and $78.9 \%$ of earth roads. These departmental roads connect the prefectures to the sub-prefectures and ensure the connection with the A network. As for class C, it comprises $35603 \mathrm{~km}$ of sub-prefectural roads (where $0.72 \%$ are paved against $99.28 \%$ in land) which provide the links between the Sub-prefectures and the village services. The rural, agricultural and forestry trails of class D connect the villages between the camps with approximately $48000 \mathrm{Km}$, according to AGEROUTE in 2010.

In total, Ivorian road network comprises $75483 \mathrm{~km}$ of dirt roads and $6650 \mathrm{~km}$ of paved roads.

The classification according to the nature gives roads in good condition, in medium and in bad condition. According to this road categorization, in 1980 more than half of the roads were in poor condition (both coated and unpaved) compared to half of paved in 1969 and a third for the unpaved roads.

The General Road Summit, initiated by the Ministry of Economic Infrastructure in April 2010, reveals that more than $85 \%$ of roads in Côte d'Ivoire were in a state of a very advanced degradation. The state of Ivorian roads today presents a very advanced decrepitude, requiring rehabilitation and emergency maintenance.

But how has this Ivorian road network evolved from temporal point of view?

\subsection{Evolution of the Ivorian Road Network over Time: $1893-2010$}

Figures 1 and 2 on the construction and development of the Ivorian road network show a spectacular evolution of this network from the colonial era to today. This road development can be divided into two main periods: from 1893 to 1957 and from 1957 up to now.

First period: from 1893 to 1957: this period is characterized by a slow growth of the Ivorian road network. It is marked by the penetration and development of the Ivorian territory. From the first major roads of type A in 1899 to the construction of the first kilometers of roads in 1923 , the Ivorian road network included $6061 \mathrm{~km}$ of which $295 \mathrm{~km}$ of military tracks and $0 \mathrm{~km}$ of asphalt road. Between 1923 and 1948 , a total of $10950 \mathrm{~km}$ of roads were built with only $0.46 \%$ of paved roads.

Second period: from 1957 to 1985 marks the strong and rapid growth of the Ivorian roads, especially the second decade after independence. This strong expansion is at the forefront of the reconstitution and integration in the national network of forest tracks and collection of agricultural products previously opened by forestry and agricultural operators. This road segment accounted for $100 \%$ and $99.5 \%$ of the road network respectively in 1933 and 1948. In 1960, Côte d'Ivoire had the lowest road patrimony in West Africa 
with $25000 \mathrm{~km}$ of roads, including $700 \mathrm{Km}$ coated. The majority of the network consists mainly of dirt roads, with a high proportion of runways. This share subsequently declined gradually from $97.3 \%$ in 1961 to $93.2 \%$ in 1980 , in favor of the paved network, whose share rose from $5 \%$ in 1948 to $6.8 \%$ in 1980 . From this date, the road network increased considerably from less than $11,000 \mathrm{~km}$ to more than $45,000 \mathrm{~km}$ in 1980 , four timesmore than the number of road kilometers in 1948. This significant public investment was financed on the one hand by the exceptional export earnings of the 1970s, and on the other hand by massive external borrowing. This spectacular development of the roads would be the basis of the strong Ivorian and historical economic growth of its kind.

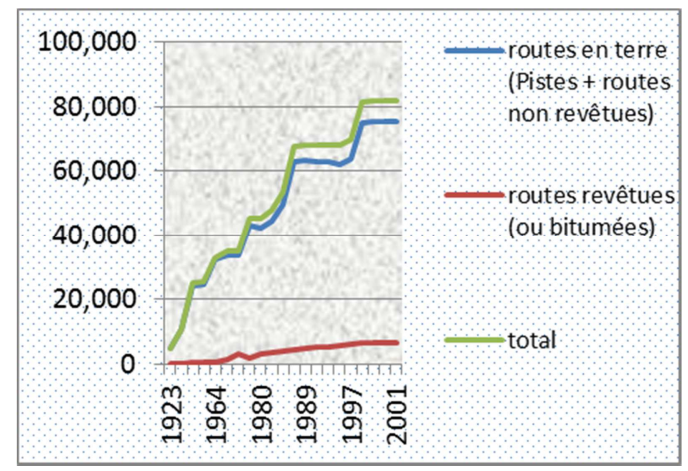

Source: Author

Figure 1. The curves of the general evolution of the Ivorian linear road network from colonization to 2002.

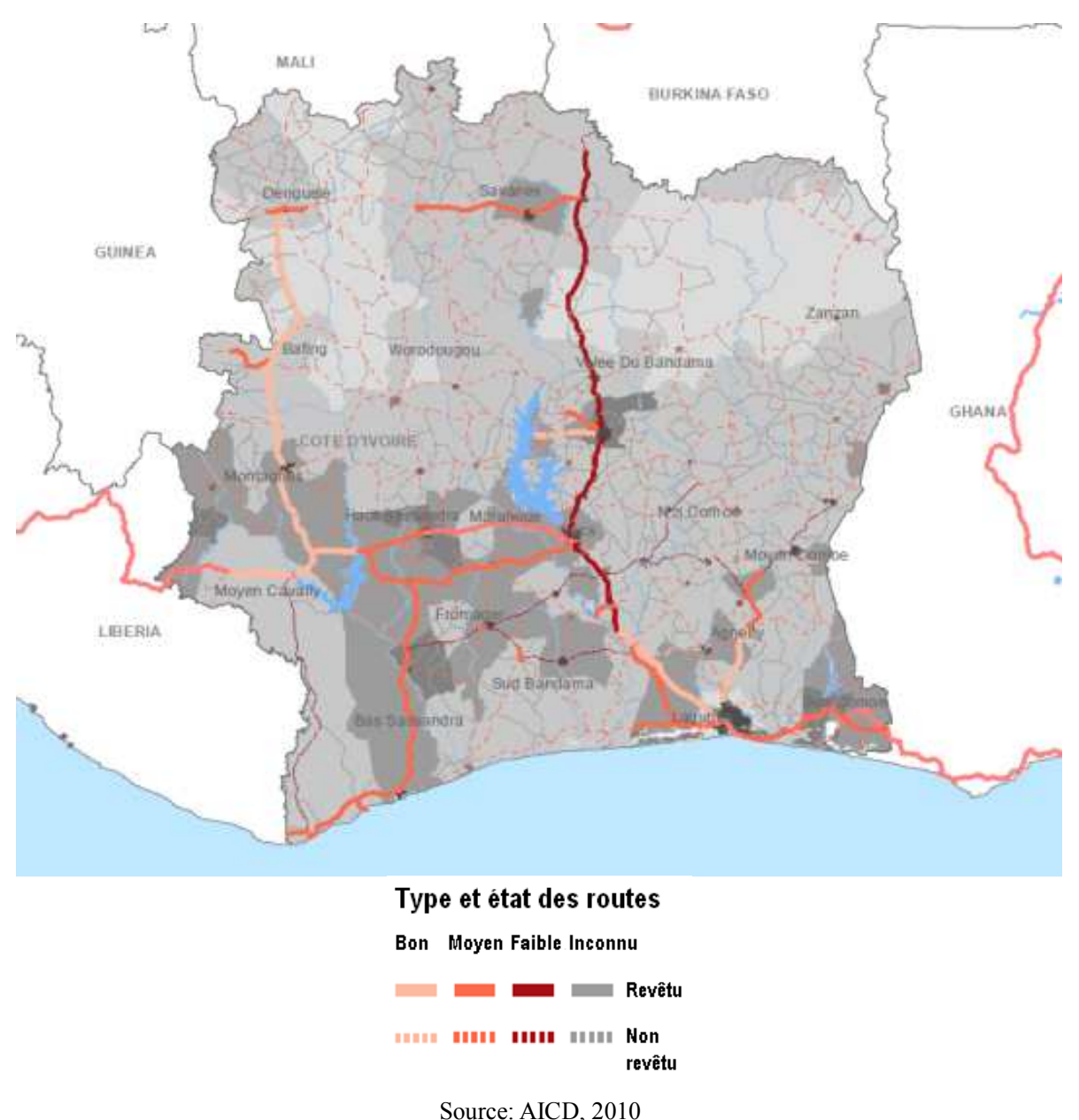

Source: AICD, 2010

Figure 2. State of Ivorian roads.

The period from 1985 to 2010 is singularly characterized by a constant evolution of paved and dirt roads (cf. figures 3 and 4). In 1985, the two types of Ivorian roads had an opposite growth rate of $0.4 \%$ upward for paved and downward for earth roads, while this rate was at $1.51 \%$ in 1990 for these two categories of roads with the same sense as in 1985. From 2010, the evolution of rates reversed, from $0.77 \%$ downward for paved and increased for roads on earth. Compared to 1980, both types of roads (on earth and paved) change rates $(1.88 \%$ and $1.11 \%$ respectively in 1990 and 2010) but without any change in sense. In total, from 1980 up to now, the Ivorian paved roads have increased on average by $0.38 \%$, while the earth roads have decreased on average by 0.38 .

The growth rates of the urban-paved network and of the major inter-urban axes have also known high trends. With more than $82,000 \mathrm{~km}$ today, the Ivorian road network recorded an increase of $15.40 \%$, for $92 \%$ of earth roads and $8 \%$ of paved roads.

In 1999, the construction of new roads stopped. There is asphalting of the existing earth roads classified high traffic and the rehabilitation and maintenance of existing roads. 


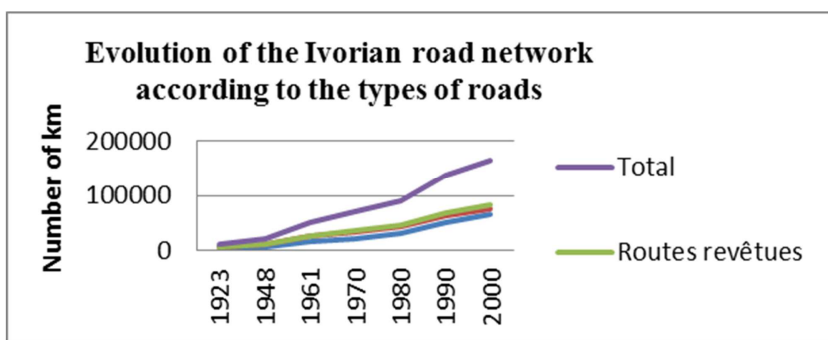

Figure 3. Comparative evolution of the different roads in Côte d'Ivoire from 1985 to 2002

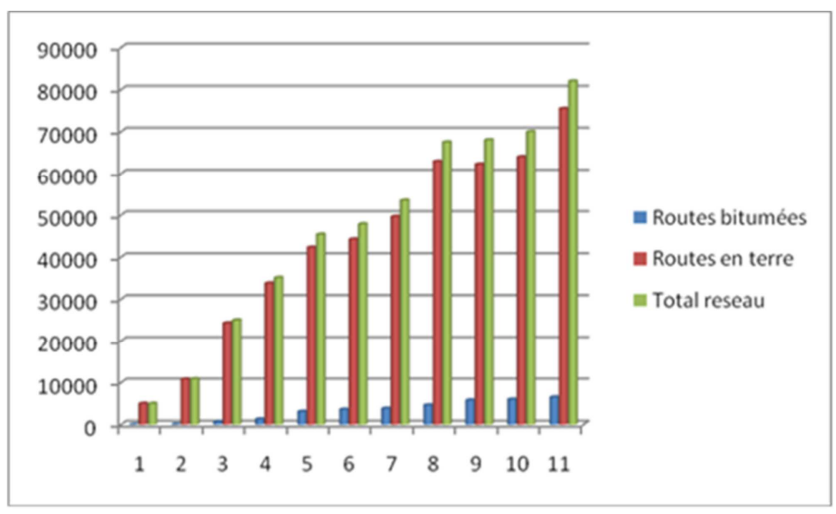

Source: Author

Figure 4. Comparative evolution of paved and earth roads in Côte d'Ivoire.

\subsection{Prioritization of the Transport System and Ivorian Growth}

In order to ensure rapidly Ivorian economic growth and collect foreign currencies, the country has adopted an opening policy based on an extrovert road network. Thus, the orientation of the network towards intraregional and interregional links is low. This road network is designed according to the economic potential of the regions, thus resulting in an unequal growth process generating North/South and city/countryside imbalances in the country. The access facilities it offers to cities compared to the countryside lead to an unequal level of growth in Ivorian localities. As part of regional development and growth, roads participate in the structuring and prioritization of industrial activities, distribution, and agricultural and artisanal exploitations, etc. The resulting transport system is highly hierarchical (Figure 5).

At the top of the hierarchy, we have the international and regional links where are generally the large traffic infrastructures supporting heavy traffic of large trucks and articulated sets (EA). These roads connect the sub-prefectures to the prefectures of the regions, and serve as links between the sub-prefectures (or prefectures) and the villages.

At the bottom of the hierarchy are rural links with agricultural tracks and unclassified earth roads where trucking is infrequent. For the local services, these roads use as a means of transport porterage, two-wheeled machines and few vans.

This is the first stage of the flow of agricultural products that dominate the rural environment with difficult transport conditions in general. However, for growth based essentially on agricultural production and its flow, the conditions of transport between the place of production and the local market are first of all importance.

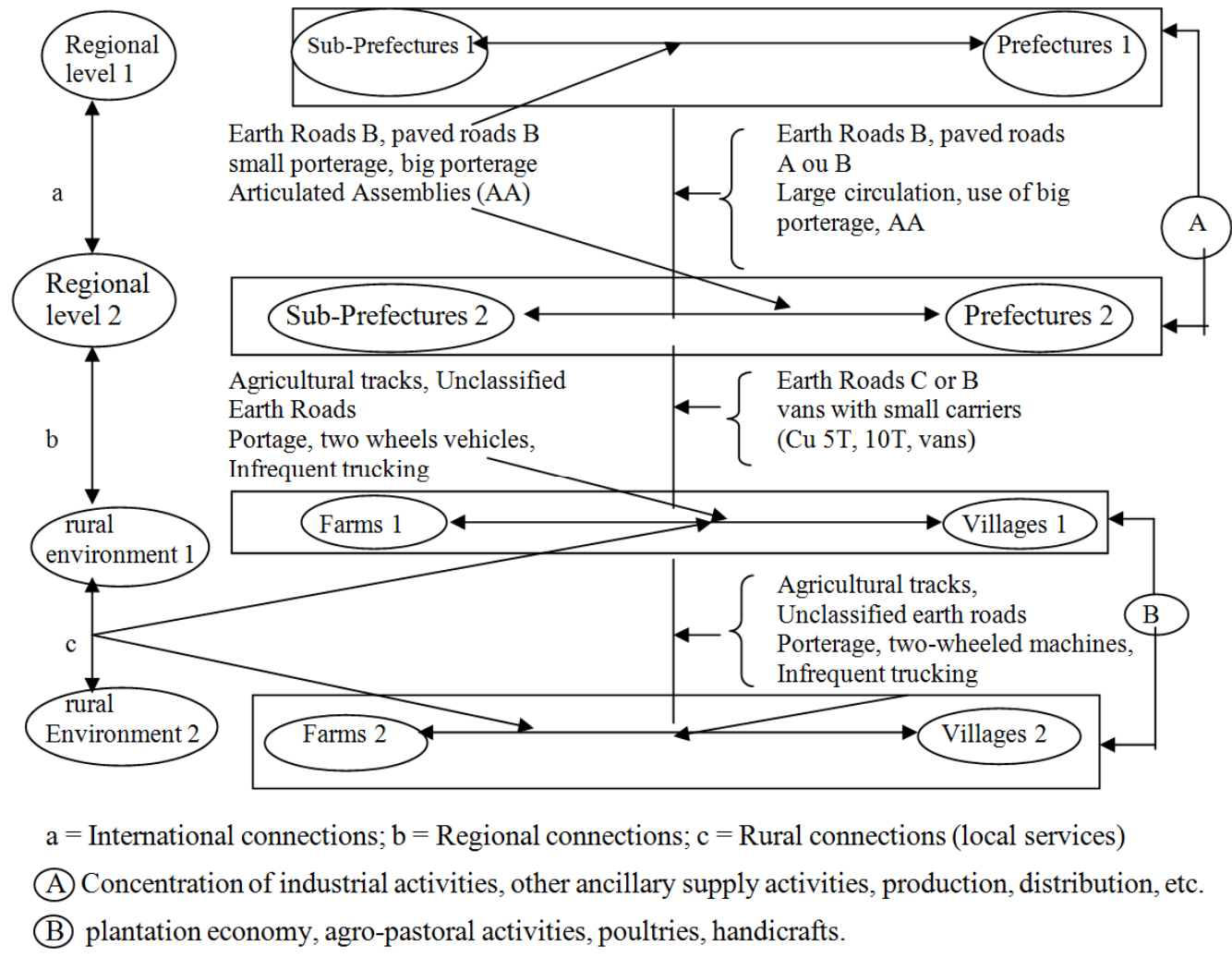

Source: Author (Goueu 2014)

Figure 5. The levels of the hierarchy of Ivorian road network. 


\subsection{Brief Literature Review on the Impact of Road Infrastructure on Growth}

The empirical studies take into account road capital contribution to the output and to the relationship between GDP growth and public infrastructures, as well as the links between public infrastructures and firm production. [5] determined road capital contribution to production, cost, and productivity growth using two macroeconomic model approaches: a neoclassical production function of Cob-Douglas and translog types including the stock of physical capital infrastructures, the public capital in the highway and other inputs with temporal or cross-sectional data; production cost and profit functions using aggregated regional and national data or time series and industry data.

Some studies analyze the relationship between GDP growth and public infrastructure [6], others link the inadequacy of private investment productivity growth to poor public investment in infrastructure [7]. The public capital stock increases the production in private sector directly and indirectly. The direct effect is the positive effect of public capital in relation to private capital and the indirect effect is the positive effect of private capital in relation to public capital or the complementarity between public and private capital in production. With a cost function, [8] determine a substitutional elasticity between public capital and private capital.

$[9,10]$ and $[11]$ showed the importance of public infrastructure capital in private sector productivity growth and the possibility of an infrastructure deficit. [12] public investment in transportation and communications greatly improves growth, and infrastructure spendings increase the social performance of other investments. The underperformance of south Saharan Africa results in the inadequacy of its infrastructures compared to that of Asia [13]. Among public investment expenditures, maintenance is very important to growth than new investments. [14] show that the sustainability of public capital is endogenous and varies according to its use and the level of maintenance expenditure. In other words, changes in total expenditures and the share of maintenance expenditures guide the steady state of the road and the dynamic behaviour of the economy.

However, Quinet model holds more our attention. It establishes an explicit relationship between transport and economic growth, and makes a modeling of the transportation supply.

\section{Methodology of Econometric Analysis by the OLS Method}

The methodology adopted in this study focuses on the presentation of models (theoretical and empirical) and data, and analysis of the estimation results.

\subsection{Theoretical Basis and Presentation of the Empirical Model}

We based our study of the analysis of roads impact on economic growth on [15] macroeconomic transport models for goods and people transport, which are themselves models of endogenous growth of Coob-Douglas type. We are making changes by incorporating accessibility and road quality indicators that take into account the particularity of Côte d'Ivoire and those of roads, and it better shows the impact of roads on the Economic growth.

The general formulation of [15] macroeconomic freight model is as follow:

$$
\mathrm{Y}=\mathrm{kX}^{\alpha}{ }_{1} \mathrm{X}_{2}{ }_{2} \mathrm{X}_{3}^{\gamma} \ldots
$$

Where $\alpha, \beta, \gamma$ are the elasticities of $X_{1}, X_{2}, X_{3}, \ldots$ respectively relative to $\mathrm{Y}$.

While his people transport model is:

$$
y_{i}=f\left(k_{i}, l_{i}, t_{i}, x_{i}\right) \times A_{i}(G)
$$

Our empirical model is an improvement of Quinet's two previous models. It is also inspired by models of endogenous and exogenous classical growth, and is easily applied to territorial and national growth through transport infrastructures. It is of the general form:

$$
Y_{i}=F\left(K_{i}, L_{i}, T_{i}, X_{i}\right) \times A_{i}(G)
$$

Where $Y_{i}$ is the national product of the year $i, K_{i}$ is the national capital in year $i, L_{i}$ is the labor force or the national active population in $i, T_{i}$ is the costs and quality of transport vector (traffic on the mode of transport, the number of seats-kilometer, etc.) that we approximate here by roads maintenance, $X_{i}$ is the overall vector of other inputs, $\mathrm{G}$ is a parameter of transport conveniences such as the capital of transport infrastructures, the number of agents per period, the size of the locality, etc., and $A_{i}(G)$ the various mechanisms of transport intervention.

$\mathrm{A}=\mathrm{B}(\mathrm{G} / \mathrm{L}), \mathrm{B}>\mathrm{O}$ is the parameter of the national intrinsic productivity

Let us replace $A$ by its expression in equation (3). We obtain a form of a Cobb-Douglas equation. In this case, the reduced and simplified production function without index $i$ is then written:

$$
\mathrm{Y}=\mathrm{BK}^{\alpha 1} \mathrm{~L}^{\alpha 2} \mathrm{~T}^{\alpha 3} \mathrm{X}^{\alpha 3} \mathrm{G}^{\alpha 3}
$$

Equation 4 can thus be linearized using the neperian logarithm. The double-log form is used to measure the effect of variation of the growth rates of the explanatory variables on the growth rate of the explained variable:

$$
\Delta \mathrm{LnY}=\alpha_{1} \Delta \mathrm{LnK}+\alpha_{2} \mathrm{LnL}+\alpha_{3} \operatorname{LnT}+\alpha_{4} \operatorname{LnX}+\alpha_{5} \operatorname{LnG}+\mathrm{w}(5)
$$

We can obtain another equation derived from (5) by introducing a dummy variable that takes into account the effects of the 1999 and 2002 coups d'Etat; of the armed rebellion, and the Ivorian military-political war in 2011.

Let us replace all variables by their expressions or proxy, and the constituent elements of the matrix X.

We obtain another equation with:

$\Delta \mathrm{LnY}_{\mathrm{t}}=\Delta \mathrm{LnPIBR}, \quad \Delta \mathrm{LnFOL}, \quad \Delta \mathrm{LnENTRO} / \mathrm{POPT}$, 
$\triangle$ LnINVPU, $\triangle$ LnINVPR, $\triangle \mathrm{LnEX}$ and $H_{j}(\mathrm{j}=1999,2002$, 2011) are respectively the growth rates of real GDP, the working population force or the national workforce, roads maintenance actually executed per capita, public investment, private investment, exports and the different crises. The stock of Ivorian capital is negative on several decades of years, for this reason we eliminate it in our analysis.

This justifies the very high level and stock of the country's debt, and therefore its use of HIPC. Also, let us take here a stock of capital per capita zero $(\Delta \mathrm{k}=0)$ in this study.

$H_{j}$ the various socio-economic crises, with $\mathrm{j}=1999,2002$ and $1999+2002$;

$w$ is the error term.

\subsection{Data Sources and Estimation of the Ivorian Model}

\subsubsection{Data Source}

We use secondary macroeconomic data because there is no yet regional roads maintenance data or regional aggregates in Côte d'Ivoire. In addition, the old divisions were made according to the climatic zones (savannah, forest, forest-west, forest-east...) and not according to the administrative or local constituencies.

The new administrative divisions are recent (the last dates from January 2012) and lack quantitative information.

Our data come from the Ministry of Economic Infrastructures, the Ivorian Treasury, the Ageroute and from the database of the World Bank. They cover all the period from 1960 till 2010.

The formalized model estimates made in this study analyze the nature of the variables (unit root tests), and use the ordinary least squares method on Eviews (cointegration, causality, impulse responses, and VECM).

$$
\operatorname{LnPIBR}=-\frac{7.0108 \operatorname{LnENTRO}}{P O P}-\begin{gathered}
29.9618 \operatorname{LnEX} \\
(5.5389)
\end{gathered}
$$

The values between the parentheses are the estimated standard deviations associated with the estimated coefficients. Consequently it is possible to estimate a vector error correction model (VECM). However, we first analyze the sense of causality between these series by using the Granger method.

The [18] and [19] causality test confirms the causal relationship between our various estimated variables. Thus, the results of this test carried out on the variables give here the rejection of the null hypothesis of non-causality:

1. At the threshold of $1 \%$, LnINVPR by LnPIBR: Because private investment causes $\ln \mathrm{PIBR}$ on the one handand on the other hand LnPIBR causes LnINVPR at the threshold of $5 \%$. This means that the predictability of LnPIBR is improved when the information related to LnINVPR is incorporated into the $1 \%$ analysis, the opposite is possible at $5 \%$

2. at the threshold of 5\%, first the GDPR causes the ENTRO/POP, the INVPU and the INVPR, then the ENTRO/POPT cause FOL and finally the private $+$

\subsubsection{Unit-root Test Procedure}

For the study of the stationarity of the variables, the first intuitions of stationarity are provided by the analysis of the graphs' evolution in the time of the log of the series and the examination of their respective correlograms. Then we apply the Augmented Dickey-Fuller (ADF) and Phillips-Perron (PP) tests. By incorporating the number of delays, the stationarity tests (ADF and FP) carried out on the variables give all series $\mathrm{I}(1)$, except the $\operatorname{lnFOL}$ variable which is $\mathrm{I}(2)$. Therefore, let us apply the method of estimation by the OLS, in two stages: to estimate the Johansen cointegration between non-stationary variables in level and to test their degree of causality. If the variables have a little evidence of cointegration relation, it means that there is a long-term relationship between theevolution of variables. We can therefore estimate the vectors of error correction model (VECM) or ECM.

\subsubsection{Johansen Cointegration and Granger Causality}

[16] and [17] cointegration test procedure is used to determine the number of cointegration vectors or the number of long-term equilibrium relationships between integrated variables that lead us to accept $\mathrm{H}_{\mathrm{o}}$ under trace and rank conditions at the meaning threshold $\alpha_{0}$.

The trace test suggests that the null hypothesis of no cointegration $(119.1297>83.973)$ is rejected at $5 \%$ threshold with at most three cointegration relationships. On the other hand, the test of Eigenvalues or rank allows us to accept the null hypothesis according to which there is a single cointegration relation $(25.508<30.439)$ between our variables at the threshold of $5 \%$.

We deduce that there is only one single long-term relationship between our variables, which is:

investment causes both the ENTRO/POPT and the EX.

3. at the threshold of $10 \%$, the INVPU causes the GDPR, the INVPU causes the INVPR, the ENTRO/POPT causes the INVPR, as well as the FOL causes the INVPU

\section{Discussion of the Results}

\subsection{Estimation of Vector Error Correction Model (VECM)}

As our variables are cointegrated, they can be represented by an error-correction model. The representation theorem of [20] demonstrates that non-stationary series, which have a unit root, must be represented as an error-correction model if they are cointegrated.

The quality of the model estimation seemsgood with regard to Fisher's statistic $\left(\mathrm{F}_{\mathrm{DLnPIBR}}=5.0713 ; \mathrm{F}_{\mathrm{DLnENTRO} / \mathrm{POPT}}=\right.$ $2.2869 ; \mathrm{F}_{\text {DLnINVPU }}=0.7198, \mathrm{~F}_{\text {DLnINVPR }}=3.250 ; \mathrm{F}_{\mathrm{DLnEX}}=$ 2.6971 ; and $\mathrm{F}_{\mathrm{DLnFOL}}=2616.991$ ) of the coefficient of determination of the six (6) estimated resulting equations of VECM. 
1) The results of the VECM estimate show that the restoring force is negative and significantly different from zero, $-0.3420 ;-1.6579 ;-1.4186$ and -0.6622 respectively in the explanatory equations for the growth rates of GDPR, the roads maintenance per capita, the private investment and the exports. These variables are characterized by a return to the long-term target, as we estimated here. They seem to return quickly from their equilibrium paths: the convergence speed is estimated at almost $16.58 \%$ and $14.19 \%$ respectively of roads maintenance and private investment. There is well an error-correcting mechanism, such as in the long term the imbalances between roads maintenance and private investment and the variables with which they are modeled offset each other so that the different series have a similar evolution.

2) On the other hand, the short-term growth rates of public investment and labor force are not characterized by a return to the long-term target, since the coefficients of their recall forces are not significantly different from zero to $5 \%$ threshold and are positive $(0.0629$ and $0.0403)$.

3) The GDPR growth rate depends on its own past values over one and two periods. It depends strongly on the rate of FOL past one and two periods, as well as the rate of the previous INVPR of a period, and finally the rate of EX delayed a period. The Ivorian GDPR is therefore influenced by exports, the labour force and private investment in Côte d'Ivoire. Which is coherent from an empirical point of view and in accordance with the economic theory that the GDP of a country according to the wealth of the nation. That is also in accordance with the causality test.

4) The maintenance of Ivorian roads depends on its own past values of one and two periods, and depends on the rate of the previous GDPR (one and two periods) as well as the rate of the previous EX of a period. It also depends on the Ivorian labour force delayed by one and two periods. This reflects the influence of GDPR, EX and FOL on ENTRO/POPT in compliance with economic theory.

5) FOL rate depends only on its own past values of one and two periods, which means that FOL is not influenced by the other variables. That is consistent from an empirical point of view and in compliance with economic theory.

6) Ivorian export rates depend on their own values and those of the GDP of a period, and the rates of INVPU, INVPR and one year FOL. Also, Ivorian exports are under the influence of INVPR, INVPU, FOL and GDPR. This is again consistent with the causality test and in compliance with economic theory.

7) Private investments in Côte d'Ivoire depend on Ivorian GDPR, exports and their own value, all for one period. They also depend on the GDPR, the FOL and their own values of two periods. This shows the influence of GDPR, ENTRO/POPT, FOL, INVPU and EX on the INVPR.
8) Unlike the private investments, Ivorian public investments depend on the GDPR, the EX, their own values, and FOL, all delayed by one and two periods. This reflects the influence of GDPR, Ex, Fol and INVPR on the INVPU.

In total, the VECM allows us to make the four (4) following remarks:

All our variables are able to reduce their short-term imbalances by returning to their long-run equilibrium level.

Exports of goods and services remain the main source of income for Côte d'Ivoire, and a strong growth in GDPR increases Ivorian exports.

GDPR and exports are determining variables in Ivorian roads maintenance, while the latter has no positive impact on Ivorian economic growth. This is still demonstrated by the long-term estimate.

The privatization of all road services (construction, maintenance, etc.) can't benefit to Côte d'Ivoire. Indeed, private investment is independent of the effects of Ivorian roads maintenance, and the impact of private investment on roads maintenance is very marginal in the case of Côte d'Ivoire. In addition, the downsizing of the Ivorian roads maintenance workers, which resulted in large maintenance deficit, is one of the major causes of the level of degradation of Ivorian roads which are greatly dependent on the Ivorian labor force. All this helps to reduce the contribution of roads to Ivorian growth.

\subsection{Test Impulses Responses}

The Impulse response functions allow the analysis of the impact of the variation of an innovation on the other variables of a VAR model. The temporal horizon of responses to shocks on the structural residuals of model variables is set at one year. The shocks are simulated over a period of fifteen years. Here, we take into account the structural innovations of the PIBR, ENTRO/POPT, EX, INVPU, INVPR and FOL variables.

A positive shock on Ivorian GDP impacts positively on the Ivorian labour force, which increases with no possibility to return to the initial equilibrium. However, it remains without effect on exports, private and public investments, and roads maintenance. Thus, an increase in Ivorian GDP improves the labour force, while it remains ineffective on exports, public and private investments and roads maintenance of the country.

Following a positive shock on roads maintenance, the GDPR reacts negatively. In contrast to the GDPR, the Ivorian labour force reacts positively and increases over the years with no possibility to return to the initial equilibrium. Exports, private and public investments are not affected in the short, medium and long terms of a shock on roads maintenance.

Therefore, we note that there is a reverse causal relationship between the GDPR and Ivorian roads maintenance. Indeed, while a shock on the GDPR has no effect on Ivorian roads maintenance, a positive shock on the latter reduces significantly the GDPR. This explains why Ivorian growth remained weak, not to say negative, after the privatization of the Ivorian road sector with the PAST and its shedding staff. Similarly, the increase in unemployment and poverty in Côte 
d'Ivoire over the last 20 years is due to the decline in roads maintenance which negatively affected the FOL by its direct correlation with it, and the latter at its turn negatively impacted on the GDPR. This creates a vicious circle of poverty and unemployment.

The impact of the positive shock of export greatly increases the GDPR over the first seven years to stabilize during the other years without being able to return to its initial equilibrium level. Quite the reverse, a positive shock on exports reduces continuously Ivorian active force without any possibility to return to initial equilibrium.

In the same vein, roads maintenance negatively responds to a shock on exports, but at a constant rhythm. This demonstrates the existence of inverse causality between exports and roads maintenance, while the first ones cause GDPR and FOL.

Following a positive shock on FOL, GDPR increases continuously over the long term. On the other hand, all the other variables are not affected by the labor force shock. This shows that the FOL does not cause the latter, so a positive shock on the labour force makes the other variables inelastic to the effects of the shock excepted the GDPR.
The response to the impact of a positive shock on the private investment of the other variables is identical to those adopted following the positive shock on public investment. Public investment in the first case, and private investment in the second case of shock, both remain positive but constant. They are therefore inelastic to these respective shocks.

However, exports and roads maintenance have the same behavior following a positive shock on the private investment than the one led on public investments. In fact, following the various socio-economic and military crises that the country has gone through, private and public investments have been adversely affected, reducing Ivorian economic growth (by declining the exports) and contributing considerably to roads degradation.

\subsection{Long Term Estimate}

After we were ensured that there is at least one cointegrating relationship through the [21] tests, we then estimate the long-term relationship between LnPIBR and the explanatory variables. The estimated long-term relationship, taking into account the crises from 1999 to 2002, is as follow:

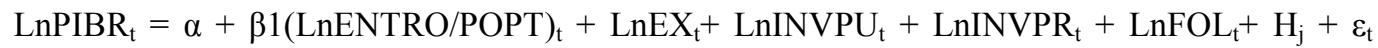

Where $H_{i}(\mathrm{i}=1,2,3)$ represents the coup d'Etat of $1999\left(H_{l}\right)$ and that of 2002 transformed into armed rebellion $\left(H_{2}\right)$ and the combined effect of both crises $\left(\mathrm{H}_{3}\right)$.

Note that not having enough observations on the roads maintenance series actually carried out for the post-war period from 2010 to 2016 , we limit our study to 2010, and therefore exclude the years 2011-2016 from our analysis.

The results of the various estimates are recorded in the following table 1:

Table 1. Summary of the estimates of equation 6 and its variants.

\begin{tabular}{llll}
\hline Variables & Estimated coefficients & Estimated coefficients & Estimated coefficients \\
\hline Constant & $-1.524(-1.95)^{* *}$ & $-1.41(-1.75)^{* *}$ & $-1.523(-1.922)^{* *}$ \\
& $0,217817^{+}$ & $0,244107^{+}$ & $0,218096^{+}$ \\
LnEntro/popt & $-0.045(-5.88)^{*}$ & $-0.046(-5.87)^{*}$ & $-1.447(-1.8)^{* *}$ \\
LnInvpu & $0.15(7.345)^{*}$ & $0.149(7.19)^{*}$ & $-0.046(-5.65)^{*}$ \\
LnInvpr & $0.125(5.63)^{*}$ & $0.123(5.49)^{*}$ & $0.15(7.176)^{*}$ \\
LnFol & $0.841(8.17)^{*}$ & $0.83(7.905)^{*}$ & $0.15(7.282)^{*}$ \\
LnEx & $0.371(6.496)^{*}$ & $0.376(6.474)^{*}$ & $0.125(5.48)^{*}$ \\
H1 & & $0.04(0.646) \mathrm{NS}$ & $0.841(8.04)^{*}$ \\
H2 & & & $0.371(6.30)^{*}$ \\
H3 & & & $0.837(8.02)^{*}$ \\
$\mathrm{R}^{2}$ & 0.997 & 0.997 & $0.0034(0.053) \mathrm{NS}$ \\
$\mathrm{R}^{2}$-adjusted & 0.997 & 0.996 & 0.997 \\
Prob(F-statistic) & 0.0000 & 0.0000 & 0.996 \\
\hline
\end{tabular}

Reading: $()=.\mathrm{t}$-statictic; $* * *=$ significant at $10 \%$ and $1 \%$ respectively; $\mathrm{NS}=$ not significant; $+:$ the coefficient $\mathrm{C}=\ln \mathrm{A}$, thus $\mathrm{A}=\exp (\mathrm{c})$ Source: Author

The results of the model estimation, taking into account socio-economic and political crises do not differ globally from the results, without taking into account of $H_{i}$ slight variations being from 1 to 2 points in the nearest thousandth. Also, our analysis will focus on the initial estimated coefficient and added estimated coefficients of $H_{i}$.

1. The GDPR estimate gives a positive coefficient for all parameters and is all significantly different from zero as expected except for the coefficient of roads maintenance. This reflects the positive impact of these variables on
Ivorian GDPR according to economic theory. Indeed, an increase of $10 \%$ in the labour force, exports, public and private investments, lead to increase the GDPR of $15 \%$, $12.5 \%, 37.6 \%$ and $84 \%$ respectively.

2. Taking into account the coup d'Etat of $1999\left(H_{1}\right)$ made without bloodshed and that of 2002 transformed into armed rebellion which had divided the country into two $\left(\mathrm{H}_{2}\right)$, as well as the combined effects of these two crises $\left(H_{3}\right)$ are all affected with positive signs. This foreshadows their positive impact on the economy of the 
country, and thus contrary to the results advocated by the economy theory. However, these crises are not significantly different from zero. Their non-significance shows that they had little impact not to say insignificant effects on the economy as a whole. Also, we can consider them as having negligible effects. Indeed 0 :

3. Although having a positive sign, the non-significance of $H_{1}$ demonstrates how the coup d'Etat of 1999 had not really affected Ivorian economy. A coup d'Etat by its nature is harmful. However, that of the year 1999 was made without bloodshed nor destruction of goods. Also, it could not impact negatively Ivorian economy as a whole.

4. The positive and non-significant sign of the rebellion of $2002\left(\mathrm{H}_{2}\right)$ which had divided the country in two, with death and destruction of goods as its consequences, in fact cannot be taken as neutral with regard to Ivorian economy. We cannot therefore conclude.

5. The positive but not significant sign of the combined effects of the $H_{1}$ and $H_{2}$ aggregation could be explained by the dominance of the $H_{1}$ effect on that of $H_{2}$, the $H_{l}$ effect supplants that of $\mathrm{H}_{2}$. However, the crisis of 1999 was minor compared to that of 2002 in scope and in consequence. Hence, the positive effect of the combination of these two crises cannot be explained either in economic theory or in fact. This result could be unrealistic and therefore difficult to interpret as we have estimated it here.

In contrast, [22] finds a negative coefficient for $\mathrm{H}_{1}(-2 \%)$ but not significantly different from zero, while the 2002 rebellion $\left(\mathrm{H}_{2}\right)$ and the overall effect of both crises $\left(\mathrm{H}_{1}\right.$ and $\left.\mathrm{H}_{2}\right)$ measured by $\mathrm{H}_{3}$ contribute negatively $(-10.27 \%$ and $-5.25 \%)$ significantly to the respective threshold of $5 \%$ and $10 \%$.

He finds that the 2002 crisis impacted more than that of 1999, but the combined effect of both crises is less. He explains the extent of the impact of the rebellion of 2002 by its extensive and destructive effects, including the war of 2011.

The roads maintenance performed head is affected by a negative sign, contrary to the expected result. Thus, $10 \%$ rise in roads maintenance per capita results in a reduction of almost $4.6 \%$ of the country's economic growth. [22] has shown that road maintenance (and not road maintenance per capita) contributes to the reduction of Ivorian growth by $1.5 \%$. The Ivorian roads maintenance carried out thus contributes thereby negatively to the economic growth of the country. This confirms our hypothesis that the actual roads maintenance budget executed per year as it cannot impact positively economic growth and the national economy as a whole.

Our results confirm those found by [23] who show that only low-quality roads $(\mathrm{km})$ and investments in low-quality roads have -1.16 and -1.57 reductive effects points, respectively, on Chinese growth. But high-quality roads $(\mathrm{km})$ and high-quality road investments have no effect on Chinese growth. Likewise, [24] show that the change in spending as a percentage of the road negatively affects the Indian growth of 0.057 , but those investments in roads have no effect on Indian growth.
However, other authors have advocated the neutrality of road infrastructures. [25] and [26], using regional panel data, found no statistically significant relationship between the growth rate of productivity of the private sector and infrastructure capital at regional level. [27] in the case of Tanzania, and [28] in that of Thailand, show that investments in roads have no effect on the economic growth of these countries. The results of studies led [29] corroborate in the same direction: neither investments in roads in murram, nor the investments in paved roads have any effect on Ugandan economic growth.

In contrast to these results, some authors find the positive impact of roads on growth. By using a global production function and time series for the United States over the period from 1949 to 1985, [10] finds estimated production elasticities relative to public capital ranging from 0.39 to 0.56 . This result was confirmed by [30] and [31], who found an elasticity of 0.33 for labor productivity and public capital, while [32] estimated a regional level of output elasticity of public capital of 0.15 compared to its national level of 0.33 for the United States. [33, 34] determine an interval of 0.08 to 0.10 of the effects of investments in road infrastructures on productivity. The studies of [35], and those of [36], covering 67 and 43 low-income countries, respectively; give an effect of the density of roads $\left(\mathrm{km} / \mathrm{km}^{2}\right)$ of $(0.012)$ and $(0.117)$ respectively on the growth of the selected countries. While, [37] find that the density of roads $\left(\mathrm{km} / \mathrm{km}^{2}\right)$ is a significant explanatory variable of growth of 0.042 points. [38] approach in the same sense and similarly argue that a road investment of 10,000 yuan has an effect of 2.12 points on Chinese economic growth.

In total, different estimates of Ivorian growth model by road transport, we retain that the Ivorian labour force has a huge impact on the Ivorian economy (84\%). The privatization of the transport sector and the various adjustment programs (including PAST-CI in 1997) with its corollary of drastically reducing the workforce (day labourers and contract employees) is therefore one of the main causes of the degradation of Ivorian roads and the weakness of national growth. In addition, roads maintenance has a negative effect on the reduction of Ivorian economic growth irrespective of the model and/or scenario adopted. Thus confirms our first two specific and main assumptions; and so that our first two objectives have been achieved. The negative impact of the Ivorian roads maintenance on economic growth, contrary to that predicted by economic theory, is justified itself by several reasons:

The roads maintenance per head includes a large part of the operating expenses. The too high weight of these operating expenses and the premiums in the roads maintenance budget partly explain the negative contribution of roads maintenance to growth. With more than $75 \%$ of the budget allocated to operating expense, premiums and fuel, there is a misallocation of the maintenance budget. We attend to a bad allocation of the maintenance budget.

The Ivorian roads maintenance budget is insufficient with regard to the kilometers of roads to be maintained (more than 
$82,000 \mathrm{~km}$ ) for an annual average of 3.85 billion over 42 years If the periods from 1969 to 1980 and from 2006 to 2010 have seen the actual execution of the entire planned budget (nil balance), the period from 1981 to 2005 is marked by a non-homogeneous change in the budgets.

The data analysis of the communities (municipalities, departments and sub-prefectures) reveals for some years that the projected budget is higher than the executed budget (1981-1984, 1986-1994, 1996-1997, 2000 and 2005) and of other years during which the budget executed is higher than the planned budget (1985, 1995, 1998-1999, 2001-2002).

The residue test estimated by the study of its autocorrelation and partial correlation correlograms shows that the residue of the regression is stationary (the P-values of Q-stat and the adjusted Q-stat are less than 0.05 of lag $=1$ to 20). Furthermore, the normality test of residues of Jarque-Bera gives $\mathrm{p}$-value $=41.02 \%>5 \%$.

The $Q$ statistic of Ljung-Box for the delay $h=12$ has a probability of $0.125>0.05$, confirms all in all the absence of autocorrelation, and the LM test of autocorrelation gives all the $\mathrm{p}$-values higher than $5 \%$, so we reject Ho and therefore the residues are not autocorrelated. In the same vein, the tests of the VEC Residual Heteroskedasticity test and VEC Residual Normality of Cholesky-Lutkepohl confirm the stationarity of the residues of the model.

In order to determine how roads maintenance can positively contribute to the performance of Ivorian economy, we set levels or thresholds for Ivorian roads maintenance.

\section{Determination of the Profitability Thresholds of the ENTRO and Estimation}

Thresholds are determined by crossing successive roads maintenance realized with private and public investments. The results obtained are recorded in the table below.

Table 2. Determination of profitability thresholds for road maintenance.

Threshold from private investment (threshold 2)

\begin{tabular}{llll}
\hline Dependent Variable: LNPIBR & & & \\
\hline Variable & Coefficient & Std. Error & t-Statistic \\
LNENTROINVPR & 93.05764 & 4.037697 & 23.04721 \\
\hline Threshold from public investment (threshold 1) & & \\
\hline Dependent Variable: LNPIBR & & & \\
\hline Variable & Coefficient & Std. Error & t-Statistic \\
LNENTROINVPU & 91.18412 & 4.095061 & 22.26685 \\
\hline
\end{tabular}

Source: Author

The inclusion of these thresholds (successively and simultaneously) has allowed a considerable improvement of the contribution of roads maintenance to Ivorian growth, from $-4.5 \%$ to $64 \%$ and $93 \%$. The analysis of the results shows us that:

1. For a threshold fixed proportionally to public investment, the contribution of roads maintenance is higher $(79.65 \%)$ than when the threshold is proportional to private investment $(64.62 \%)$. This contribution of roads maintenance is more advantageous when the threshold is determined proportionally to both private and public investments $(91.63 \%)$. Thus, the fixing of the amount of the annual roads maintenance budget in proportion to public investment (threshold 1) provides a higher contribution of roads maintenance, exports, labour force, and private and public investments compared to their contributions proportionally to private investment (threshold 2).

2. Similarly, by fixing the level of the annual budget of roads maintenance in proportion to the amounts of private and public investments concomitantly, only the contribution of roads maintenance to economic growth is greatly improved by about $92 \%$. However, the impact of exports on growth was reduced compared to those obtained with thresholds 1 and 2 .

The analysis of the estimated results of the different Ivorian politico-military crises with the thresholds shows that the indexation of road investments to public investments improves the effects of coups d'Etat and more advantage with the indexation of these road investments to private investments only in the absence of indexation. This shows that private investments have the capacity to absorb political-military crises in Côte d'Ivoire.

Table 3. Summary of the two thresholds taken simultaneously.

\begin{tabular}{|c|c|c|c|c|}
\hline \multirow{2}{*}{ Variables } & \multicolumn{4}{|c|}{ Estimate with combined thresholds 1 and threshold 2} \\
\hline & Estimated Coefficient OLS. & Estimated Coefficient & Estimated Coefficient & Estimated Coefficient \\
\hline \multirow{2}{*}{ Constance } & $6,382(6,581)^{* *}$ & $6.4075(6.5486)^{*}$ & $6.47(6.632)^{*}$ & $6.39(6.489)^{*}$ \\
\hline & $591,109^{+}$ & $606,376^{+}$ & $645,484^{+}$ & $595,857^{+}$ \\
\hline LnEntro/popt & $0.916(8.528)^{*}$ & $0.91(8.3697)^{*}$ & $0.9302(8.566)^{*}$ & $0.92(8.326)^{*}$ \\
\hline LnInvpu & $-0.078(-2.172) * *$ & $-0.079(-2.198)^{* *}$ & $-0.08(-2.24)^{* *}$ & $-0.078(-2.142)^{* *}$ \\
\hline LnInvpr & $0.03(1.1) \mathrm{NS}$ & $0.031(1.139) \mathrm{NS}$ & $0.025(0.915) \mathrm{NS}$ & $0.029(1.031) \mathrm{NS}$ \\
\hline LnFol & $0.886(15.486)^{*}$ & $0.8796(15.076)^{*}$ & $0.883(15.404)^{*}$ & $0.8865(15.23)^{*}$ \\
\hline
\end{tabular}




\begin{tabular}{|c|c|c|c|c|}
\hline \multirow{2}{*}{ Variables } & \multicolumn{4}{|c|}{ Estimate with combined thresholds 1 and threshold 2} \\
\hline & Estimated Coefficient OLS. & Estimated Coefficient & Estimated Coefficient & Estimated Coefficient \\
\hline LnEntro/invpu & $-17.103(-5.677)^{* *}$ & $-17.235(-5.66)^{*}$ & $-17.15(-5.68)^{*}$ & $-17.08(-5.59)^{*}$ \\
\hline LnEntro/invpr & $-7.501(-2.427)^{*}$ & $-7.215(-2.294)^{* *}$ & $-7.783(-2.503)^{* *}$ & $-7.604(-2.39)^{* *}$ \\
\hline $\mathrm{H} 1$ & & $0.023(0.669) \mathrm{NS}$ & & \\
\hline $\mathrm{H} 2$ & & & $-0.033(-0.95) \mathrm{NS}$ & \\
\hline H3 & & & & $-0.005(-0.189) \mathrm{NS}$ \\
\hline $\mathrm{R}^{2}$ & 0.9991 & 0.999 & 0.9992 & 0.9991 \\
\hline $\operatorname{Pr}(\mathrm{F}$-stat $)$ & 0.0000 & 0.0000 & 0.0000 & 0.0000 \\
\hline
\end{tabular}

Reading: $()=$. T-statictic, $* * *$ Significant at $5 \%$ and $1 \%$ respectively; $N S=$ Not significant,+ the coefficient of $A=\exp (\mathrm{c})$, with $C=\ln A$ Sources: Author

\section{Conclusion}

From all these results, we advocate the following recommendations:

The variable of interest, roads maintenance has a negative reducing effect on Ivorian economic growth. The road cannot positively affect Ivorian growth if investments in the sector reach a certain level compared to other investments. Also, it would be good that the State defines for each year, a roads maintenance budget in proportion to $91.20 \%$ the annual public investment budget or $93 \%$ of the private investment budget to allow the road to increase significantly Ivorian real GDP.

The labour force strongly contributes to the increase of Ivorian growth $(84 \%)$. It is then advisable to set up policies adapted to the evolution of the economic and social system, and policies of integration of active persons, including unemployed graduated young people and the unemployed from 2011 crisis, should be put in place.

The rebellion and the aggregation of crises give a noticeable reduction effect on growth; therefore, it will also be necessary to put in place mechanisms to prevent social crises (in particular rebellion and war), such as the case of the ex-rebels' claims on January 2017. The fight against poverty necessarily involves the elimination of discrimination between regions.

Ivorian authorities must take appropriate measures for granting public procurement contracts to the private sector by promoting call for tenders with specifications; and to promote the agents according to their ability and aptitude and not according to relations of clientelism as it is current in Côte d'Ivoire.

Short-and long-term econometric estimates and those taking into account the Ivorian crises of 1999-2002 give private and public investments and exports from Côte d'Ivoire, a strong contribution to the national growth of $15 \%, 12.5 \%$ and $37.3 \%$ respectively. They are key determinants of national economic growth. These variables are economic policy leverage instruments that the authorities must use to revive strong and sustainable growth in Côte d'Ivoire.

The government must encourage private investment and the development of big-capacity export activities, the only way to reach the country's emergence; while keeping to privatize all compagnies under the pretext of the satisfaction of foreign commitments or comply with the capitalist system. Also, the State should encourage the development of high-capacity exporting activities and especially coming from the private sector, which through its production and taxes paid, could be the dorsal column of the future sung emergence.

In view of the results of the causality tests and the impulse response defining the relationship between private investments and roads maintenance, we propose that the State of Cote d'Ivoire implements measures in the road sector to encourage the private investors to invest in roads and even more in roads maintenance.

\section{References}

[1] Antonio E. (2007), «Infrastructures et développement: une revue des débats récents et à venir», Revue d'économie du développement, 4 (volume 21).

[2] Kouadio Y. (1993) "Rétrospective Economique de la Côte d'Ivoire", Etude NationaleProspective scrétariat Technique Permanent, 8 Décembre.

[3] Meleu M. (1994), «Croissance Economique en Côte d'Ivoire: sources, contraintes etfluctuations», Miméo-Crémid.

[4] Pégatienan H. J. (1994), "Les sources de la croissance économique en Côte d'Ivoire", D. T. No 5, Décembre.

[5] Khanam R. B. (1999), Contributions of highway capital to output, cost, and productivity growth: evidence from (Tm) Canadian goods-producing sector, A thesis submitted to the Faculty of Graduate Studies in partial fulfillment of the requirements for the degree of Doctor of Philosophy; Graduate Program in Economics York University North York, Ontario, December.

[6] Fernald, J. G., (1999), "Roads to Prosperity? Assessing the Link Between Public Capital and Productivity", The American Economic Review, June, 619-638.

[7] Gillen, D. W., (1996), "Transportation Infrastructure and Economic Development, Logistics and Transportation Review, 32: 1, 39-69.

[8] Morrison C. et A. E. Schwartz (1996) «State infrastructure and productive performance», The American Economic review, dec.

[9] Aschauer D. A. (1989), «Public Investment and Productivity Growth in the Group of Seven», Economic Perspectives, 13 (5): $17-25$.

[10] Aschauer, D. A. (1989), «Does Public Capital Crowd Out Private Capital?», Journal of Monetary Economics, 24 (2): 171-188. 
[11] Munnell A. H. (1990) How does public infrastructure affect regional economic performance? New England Economic Review, Sept-Oct, 11-32.

[12] Easterly W., Rebelo S. (1993) «Fiscal Policy and Economic Growth: An Empirical Investigation», Journal of Monetary Economics, (32), Décembre, PP. 417-458.

[13] Collier P. and J. W. Gunning (1999) Explaining African Economic Performance, Journal of Economic Literature, vol 37, mars.

[14] Kalaitzidakis P. et S. Kalyvitis (2004) "On the macroeconomic implications of maintenance in public capital", Journal of Public Economics, 88 (3/4): 695-712.

[15] Quinet E. (1998), «Principes d'Economies des Transports», Ed. Economica.

[16] Johansen, S. (1995). A statistical analysis of cointegration for I(2) variables. Econometric Theory, 11 (1), 25-59.

[17] Johansen, S. (1996). Likelihood-based Inference in Cointegrated Vector Autoregressive Models, (2nd ed.) Oxford University Press, Oxford.

[18] Granger, C. W. J. (1969). "Investigating Causal Relations by Econometric Modelsand Cross-spectral Methods". Econometrica. 37 (3): 424-438.

[19] Granger Clive W. J., 1980, "Testing for causality: A Personal Viewpoint", Journal of Economic Dynamics and Control, 2, 329-352.

[20] Engle R. F. et C. W. J. Granger (1987), Cointegretion and error correction: Representation, Estimation and Testing, Econometrica, 55, 251-276.

[21] Johansen, S. (1997). Likelihood inference in the I (2) model, Scandinavian Journal of Statistics, 24, 433-462 (1997).

[22] Goueu Zran Fulgence (2014) Interurban transport offer and economic growth: case of Côte d'Ivoire, PhD Es-Economics, FHB University of Cocody Abidjan, Thesis Unique, chapter 2.

[23] Fan, S., et C. Chang-Kang (2005) Road Development, Economic Growth, and Poverty Reduction in China. IFPRI Research Report 138, International Food Policy Research Institute Research, Washington DC.

[24] Fan, S., P. Hazell, et S. Thorat (2000) "Government Spending, Growth, and Poverty in Rural India." American Journal of Agricultural Economics 82 (4): 1038-51.

[25] Hulten, C. R. and R. M. Schwab (1991), '1s There Too Little Public Capital?", Infrastructure and Economic Growth, Conference Paper, March.
[26] Tatom J. A. (1993) Is an infrastructure crisis lowering the nation's productivity? Federal Reserve Bank of Saint-Louis Review, 75 (6), 3-21.

[27] Fan, S., D. Nyange, et N. Rao (2005) "Public Investment and Poverty Reduction in Tanzania: Evidence from Household Survey Data." DSGD Discussion Paper 18, International Food Policy Research Institute, Washington, DC.

[28] Fan, S., S. Jitsuchon, et N. Methakunnavut (2004) "The Importance of Public Investment for Reducing Rural Poverty in Middle-Income Countries: The Case of Thailand." DSGD Discussion Paper 7, International Food Policy Research Institute, Washington, DC.

[29] Fan S., X. Zhang, et N. Rao (2004) "Public expenditure, growth, and poverty reduction in rural Uganda." IFPRI Discussion paper, International Food Policy Research Institute, Washington, DC.

[30] Serkan Arslanalp, Fabian Bornhorst, Sanjeev Gupta, and Elsa Sze (2010), Public Capital and Growth, International Monetary Fund WP/10/175, July.

[31] Pierre-Richard Agénor and Blanca Moreno-Dodson (2006), Public Infrastructure and Growth: New Channels and Policy Implications, World Bank Policy Research Working Paper 4064, November.

[32] Munnell Alicia H. (1992) «Infrastructure Investment and Economic Growth » Journal of Economic Perspectives, Policy Watch - Volume 6, Number 4 — Pages 189-198.

[33] Prud'homme R. (1997), «Assessing the role of infrastructure in France by Means of Regionally Estimated Production Function», in Infrastructure and the Complexity of Economic Development, D. Batten and C. Karlsson editors, Springer.

[34] Fritsch B. et R. Prud'homme (1997), «Measuring the Countribution of Road Infrastructure to Economic Development in France», Macmillan.

[35] Craig, B. J., P. G. Pardey, et J. Roseboom (1997) “International Productivity Pattern: Accounting for Input Quality, Infrastructure, and Research." American Journal of Agricultural Economics 79 (4): 1064-78.

[36] Fan, S., et N. Rao (2003) "Public Spending in Developing Countries: Trends, Determination, and Impact." EPTD Discussion Paper 99, International Food policy Research Institute, Washington, DC.

[37] Fan, S., et X. Zhang (2004) "Infrastructure and Regional Economic Development in Rural China." China Economic Review 15 (2): 203-14.

[38] Fan, S., L. Zhang, et X. Zhang (2002) Growth, Inequality, and Poverty in Rural China: The Role of Public Investments. IFPRI Research Report 125, International Food Policy Research Institute, Washington, DC. 